\title{
EXPERIMENTAL USE OF FIBRIN GLUE DERIVED FROM SNAKE VENOM IN NON-PREGNANT CANINE UTERUS
}

\author{
MORAES, J.R.E. ${ }^{1}$; CORREIA, P.H.A. ${ }^{1}$; CAMPLESI, A.C. ${ }^{1}$; MORAES, F.R. ${ }^{1}$
}

${ }^{1}$ Departamento de Patologia Veterinária, Faculdade de Ciências Agrárias e Veterinárias, Universidade Estadual Paulista (UNESP), Jaboticabal, São Paulo, Brasil.

\begin{abstract}
This study evaluated the use of fibrin glue derived from snake venom in the healing process after canine hysterorrhaphy. Three groups of four animals were submitted to uterine hysterotomy followed by wound closure. In Group 1, double-layer suture was used, the first with Schimieden pattern, the second with Cushing pattern; in Group 2, only fibrin glue; and in Group 3, the same as for Group 1 but with fibrin glue as suture reinforcement. Results indicated that fibrin glue produced less inflammation in the exudative phase, and exacerbated deposition of connective tissue and angiogenesis in the proliferative and maturation phases of the healing process, favoring its evolution.
\end{abstract}

KEY WORDS: healing, fibrin glue, uterus, surgical adhesives, wound closure.

\section{CORRESPONDENCE TO:}

J. R. E. de Moraes - Laboratório de Patologia Experimental e Comparada, Departamento de Patologia Veterinária, Universidade Estadual Paulista (UNESP), Campus de Jaboticabal, Via de Acesso Prof. Dr. Paulo Donato Castellane, s/n, 14.884900, Jaboticabal, São Paulo, Brasil.

E-mail: jrmoraes@fcav.unesp.br 
J. R. E. de Moraes et al. EXPERIMENTAL USE OF FIBRIN GLUE DERIVED FROM SNAKE VENOM IN NONPREGNANT CANINE UTERUS. J. Venom. Anim. Toxins incl. Trop. Dis., 2004, 10, 2, p.134.

\section{INTRODUCTION}

Fibrin adhesives derived from snake venom are originally composed of plasma protein and snake venom (Crotalus durissus terrificus), imitating the last steps of the coagulation cascade, with the formation of a fibrin network (6). Bovine fibrinogen interacts with the "thrombin-like" fraction of snake venom, releasing monomeric fibrin. This, in the presence of calcium and factor XIII is converted into a polymer with adhesive properties (13). This adhesive, used in human skin grafts, shows total adhesion in $71.4 \%$ of patients and partial adhesion in $28.6 \%$, which makes it a valuable alternative in skin surgery (11).

In animals, fibrin glue has been used in ram testicular biopsies to test its hemostatic and healing capacity. The results have shown that fibrin glue is to apply, requires short postoperative monitoring, and presents fast, good-quality skin healing (10). When used for peripheral nerve repair in rats using autologous nerve grafting, fibrin glue was much more effective than terminal lateral neurorrhaphy, producing a higher regeneration rate (9). In a similar model comparing conventional epineural suturing with fibrin glue derived from snake venom on sciatic nerve coaptation in Wistar rats, both techniques showed similar results, but fibrin glue presented better regeneration (14).

Commercial fibrin glue has been successfully used in humans for closure of bronchopleural fistulas in newborns with pneumonia and pneumothorax (3). In order to reduce contamination risks, several methods for producing autologous fibrinogen, such as cryoprecipitation from the patient's own blood have been developed in the last five years. Autologous fibrin glue is an interesting alternative, however, it can only be used in elective and programmed surgeries (13).

Biological fibrin glue showed better hemostatic and sealing effects in the reinforcement of cardiovascular sutures than biological sealants containing cryoprecipitate, which only showed hemostatic effect, and GRFG (Gelatin-Resorcinol-FormaldehydeGlutaraldehyde) adhesive that was effective as a reinforcement, but with limited hemostatic action (1). 
J. R. E. de Moraes et al. EXPERIMENTAL USE OF FIBRIN GLUE DERIVED FROM SNAKE VENOM IN NONPREGNANT CANINE UTERUS. J. Venom. Anim. Toxins incl. Trop. Dis., 2004, 10, 2, p.135.

In experimentally induced wounds in rat livers, those treated with biological fibrin glue showed larger quantity of young collagen and higher angiogenesis (4) in comparison to those treated with cyanoacrylate.

The hemostatic effect of autologous fibrin glue derived from snake venom and the increase in granulation tissue were demonstrated in skin grafts when compared to second intention healing, although the histological alterations were not different (7).

The fibrin glue used in this study was composed of the thrombin-like fraction of Crotalus durissus terrificus venom, mixed with bovine plasma, and calcium chloride. The association of these three components forms a fibrin network, similar to a clot (13), in the wound site.

The objective of this study was to evaluate healing process evolution in canine uterine hysterorrhaphy, using fibrin glue derived from snake venom as a substitute for or reinforcement to suturing in non-pregnant adult bitches.

\section{MATERIALS AND METHODS}

\section{Animals}

Twelve adult bitches of unknown breed were used. After being examined and considered clinically healthy, the animals were randomly divided into three groups of four; the uteri were submitted to three different surgical treatments of bilateral hysterotomy followed by wound closure. The bitches were pre-anaesthetized with chlorpromazine $(1 \mathrm{mg} / \mathrm{kg})$ and then an association of tiletamine and zolazepan chlorate $(0.2 \mathrm{ml} / \mathrm{kg})$ by intra-muscular injection (IM), as per classical surgical procedure. In Group 1, we used double-layer suture, the first with Schimieden pattern and the second Cushing pattern with absorbable synthetic 4-0 (Dexon $\left.{ }^{\circledR}\right)$, mounted on atraumatic needle in eigth uterus. In Group 2 fibrin glue only was used for the coaptation of uterine horn edges. The use of this material was preceded by digital compression of the uterine artery to achieve hemostasis and drying of wound edges with gauze. Without interruption and 
J. R. E. de Moraes et al. EXPERIMENTAL USE OF FIBRIN GLUE DERIVED FROM SNAKE VENOM IN NONPREGNANT CANINE UTERUS. J. Venom. Anim. Toxins incl. Trop. Dis., 2004, 10, 2, p.136.

using the fingers, perfect coaptation of the surgical wound edges was maintained for a few seconds. In Group 3, we used the same procedure as described for Group 1 associated with fibrin glue as suture reinforcement; the technique used was similar to the other two groups.

The fibrin glue used in this study was provided by Centro for the Study of Venoms and Venomous Animals (CEVAP), UNESP. At the time of hysterectomy, all uteri were evaluated for coloration, adherences, stenosis, or other alterations which might lead to excluding the animal.

The animals were hysterectomized at different times after surgery (three, seven, 15, and 30 days) and their uteri collected for morphological evaluation.

Macroscopic evaluation of surgical wounds was made daily during dressing changes until a scar was formed.

The hysterectomized uteri were macroscopically evaluated, and a fragment of each injured area was collected. These were washed in $0.9 \%$ saline, fixed in Bouin for $24 \mathrm{~h}$, then washed in $70 \%$ alcohol. Later, they were processed by usual techniques for embedding in paraffin. From each segment, $4 \mu \mathrm{m}$ thick cuts were made, and stained with hematoxylin eosin for later comparative evaluation of the healing process under light microscopy. The alterations of the exsudative, proliferative, and maturation phases of the inflammatory and healing process were described.

\section{RESULTS}

\section{Macroscopic evaluation}

The animals showed satisfactory clinical evolution, with perfect tolerance to the surgical treatments throughout the post-operative observation period. Uterus color was normal The wound healed by first intention, even in the females that were re-submitted to surgery with less than seven days of post-operative evolution. No stenosis or adherence was observed. 
J. R. E. de Moraes et al. EXPERIMENTAL USE OF FIBRIN GLUE DERIVED FROM SNAKE VENOM IN NONPREGNANT CANINE UTERUS. J. Venom. Anim. Toxins incl. Trop. Dis., 2004, 10, 2, p.137.

\section{Microscopic evaluation of the healing process}

Uterine lesions in all groups were similar between the third and seventh days. In this stage, there was a prevalence of congestive and hemorrhagic alterations and accumulation of inflammatory cells, predominantly mononuclear cells with a smaller quantity of neutrophils. Group 1 showed more inflammation than Groups 2 and 3, with higher leukocyte accumulation, especially around the suture thread. In the groups using fibrin glue, there was less inflammatory cell accumulation. In all three groups, the uterine epithelium was partially regenerated; perimetrium coaptation was complete in Groups 1 and 3, where hysterorrhaphy was performed. Healing was more exuberant and with more connective tissue in Group 2 than in Groups 1 and 3 (Figure 1).

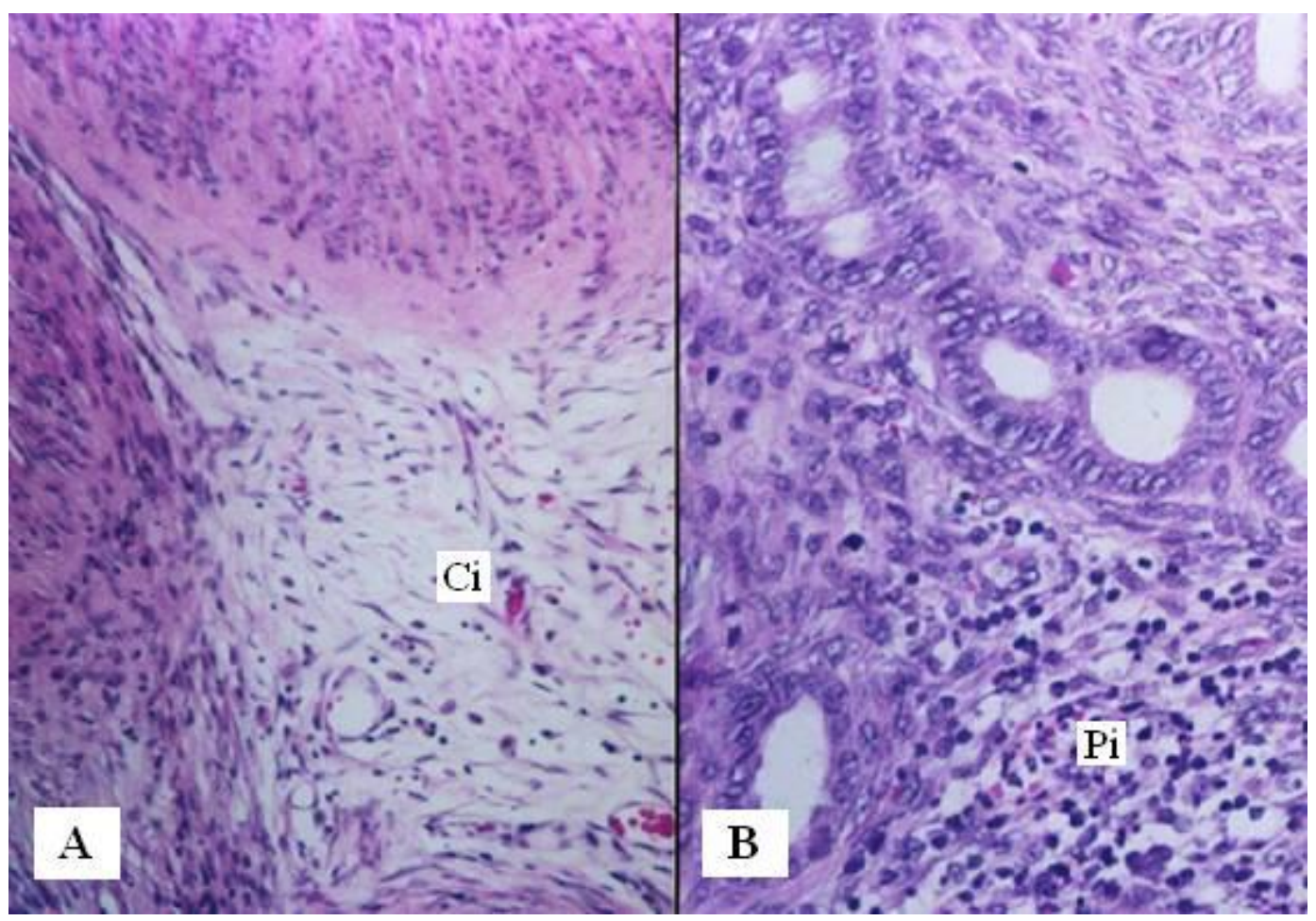

Figure 1. Microscopic aspect of the uterus 7 days after surgery- A = exudative phase, exuberant healing in $\mathrm{G}_{2}(\mathrm{Ci})$. $\mathrm{B}=$ inflammatory cells in $\mathrm{G}_{3}(\mathrm{Pi})$ glandular chorion. Staining HE (300x). 
J. R. E. de Moraes et al. EXPERIMENTAL USE OF FIBRIN GLUE DERIVED FROM SNAKE VENOM IN NONPREGNANT CANINE UTERUS. J. Venom. Anim. Toxins incl. Trop. Dis., 2004, 10, 2, p.138.

Between eight and fifteen days after surgery, the process was highly proliferative. The epithelium was totally regenerated regardless of the treatment. Many neo-formed vessels were diffusely arranged in the sub-epithelial and glandular chorion layers. Less mononuclear inflammatory cells were seen in all three groups than in the earlier period; they could be seen in the injured area until the $15^{\text {th }}$ day after surgery. However, the inflammatory cell accumulation in Group 2 was half that of Groups 1 and 3. The subepithelial chorion showed formation of abundantly vascularized granulation tissue rich in loose connective tissue, especially in Groups 2 and 3 (Figure 2).

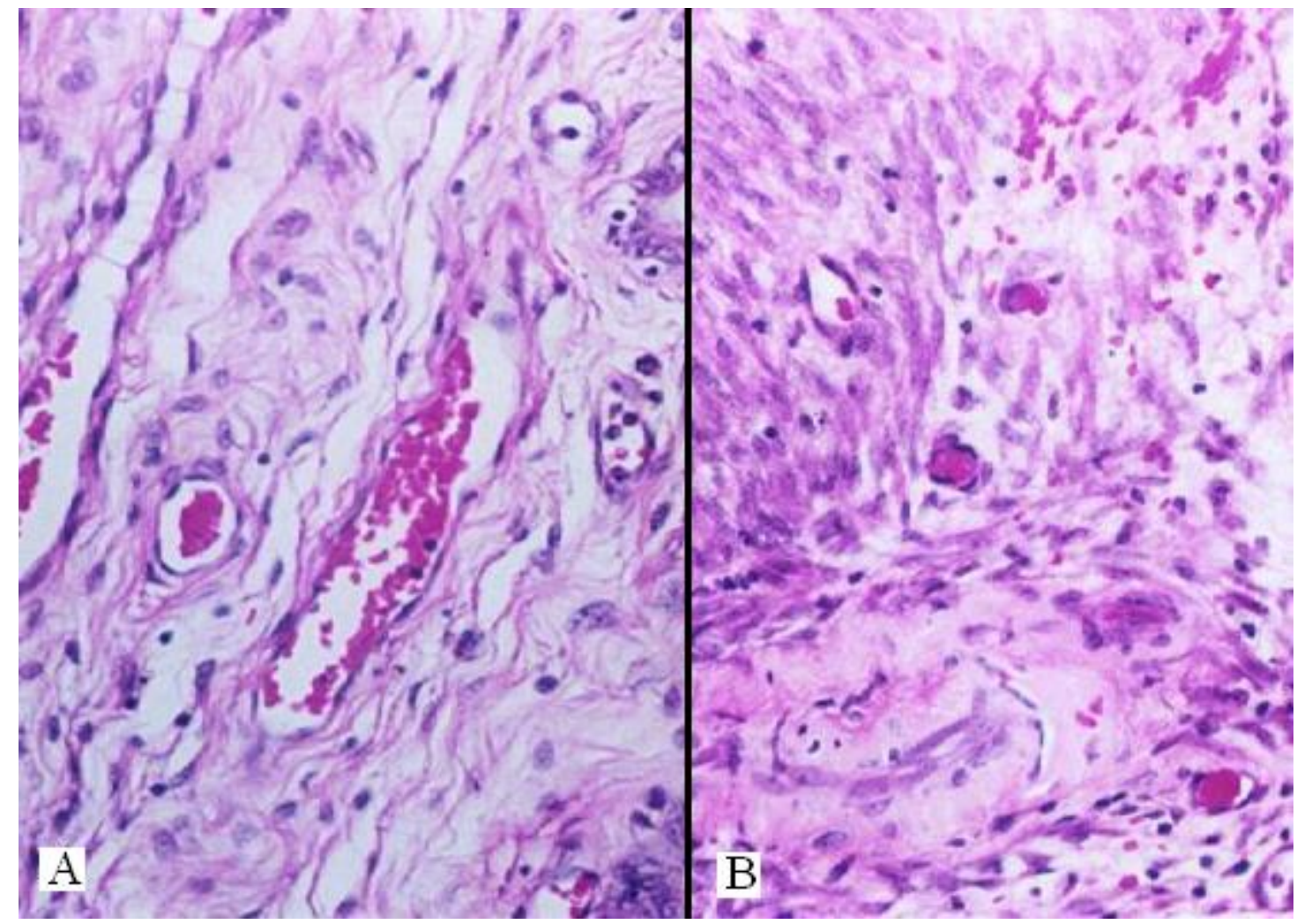

Figure 2. Microscopic aspect of the uterus 15 days after surgery- $A=$ proliferative phase, abundant loose connective tissue, and vascular congestion in $G_{3}$. B = large number of neo-vessels and hemorrhage of $\mathrm{G}_{1}$ healing tissue. Staining HE (300x). 
J. R. E. de Moraes et al. EXPERIMENTAL USE OF FIBRIN GLUE DERIVED FROM SNAKE VENOM IN NONPREGNANT CANINE UTERUS. J. Venom. Anim. Toxins incl. Trop. Dis., 2004, 10, 2, p.139.

During the maturation phase, between 16 and 30 days post surgery, the three groups showed total epithelium regeneration, regardless of the treatment. Some uteri presented more exuberant epithelial hyperplasia, especially Group 2. There was less vascularization, and inflammatory cell infiltrate was still evident in Groups 1 and 3, but not in Group 2. The sub-epithelial and glandular chorion layers were reorganized, and healing tissue remodeling was seen in all groups. Tissue healing thickness was higher in Group 2 than in Groups 1 and 3 (Figure 3).

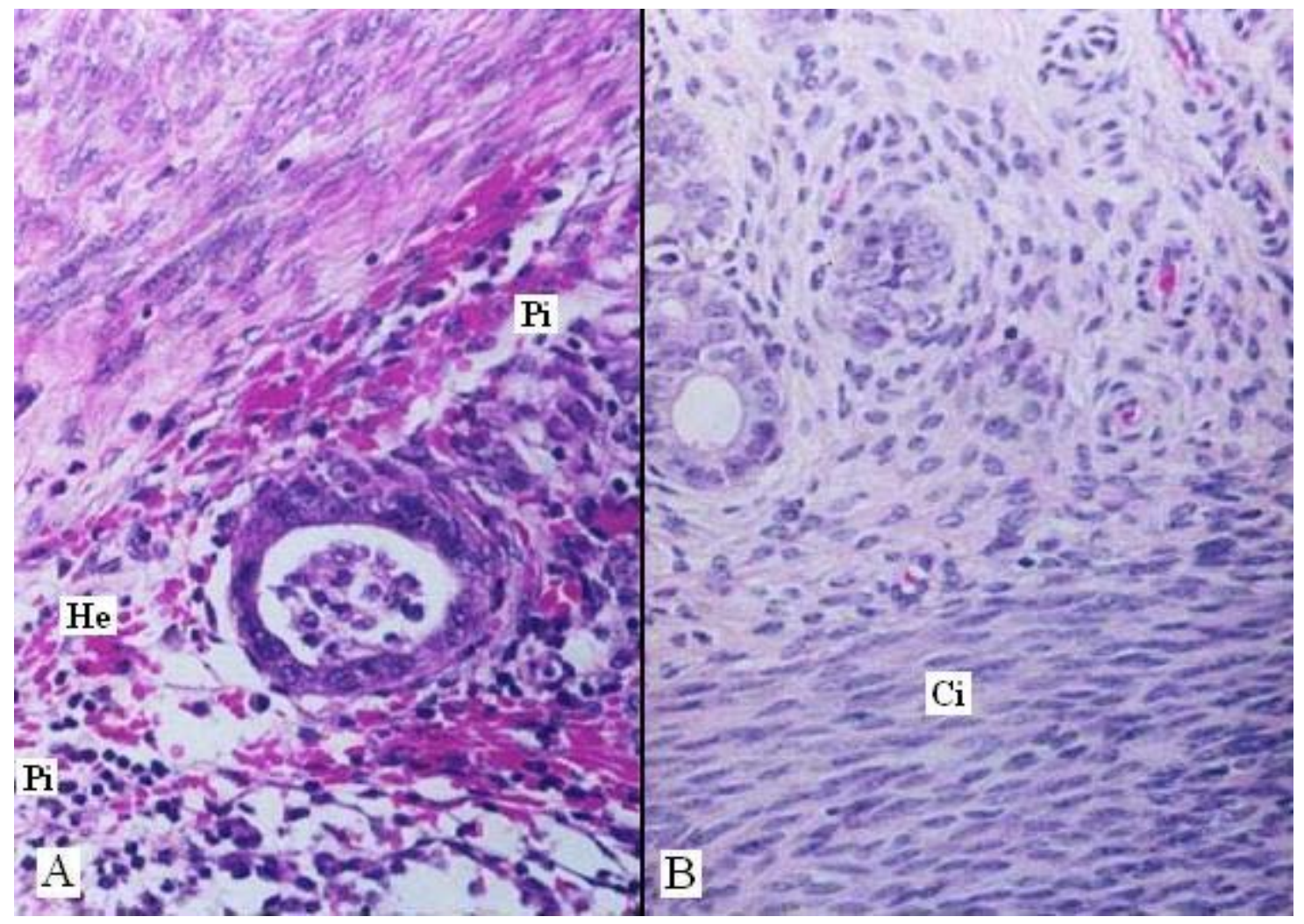

Figure 3. Microscopic aspect of the uterus 30 days after surgery $-\mathrm{A}=$ regenerative phase, concentration of inflammatory cells ( $\mathrm{Pi}$ ) and hemorrhage $(\mathrm{He})$ in $\mathrm{G}_{1} . \mathrm{B}=$ scar reorganization in $\mathrm{G}_{2}$. Staining HE (300x). 
J. R. E. de Moraes et al. EXPERIMENTAL USE OF FIBRIN GLUE DERIVED FROM SNAKE VENOM IN NONPREGNANT CANINE UTERUS. J. Venom. Anim. Toxins incl. Trop. Dis., 2004, 10, 2, p.140.

\section{DISCUSSION}

Applicability of the fibrin glue derived from snake venom has been tested in different situations, both in experimental animals and humans $(2,5)$.

The use of this sealant adhesive on surgical wounds in rabbits has suggested its efficiency in the healing process (12).

The results of this study show that the fibrin glue derived from snake venom induces a higher accumulation of connective tissue and fibroblasts in healing tissue. These results are similar to those seen in rat colon anastomosis, where the same glue showed a significant reduction in surgical time, immediate hemostais, and a higher quantity of granulation tissue (5). The utilization of commercial autologous fibrin glue as suture reinforcement in human malignant skin tumors (7) has also shown good results. However, when fibrin glue was used in ram testicular biopsy (10) with excellent results in conventional hysterorrhaphy of ovine caesarean section (2), wound dehiscence occurred followed by peritonitis, which indicates limitations for the use of this technique.

In our study, there were histological differences between the groups, with a higher formation of granulation tissue when fibrin glue was used. This may result from the fact that fibrin forms a real network or crust uniting the wound edges, allowing and facilitating the transit, adherence, migration, proliferation, and differentiation of repair cells such as fibroblasts and endothelial cells $(15,16)$.

Microscopic evaluation showed that in the suture only group (G1), there was a large number of inflammatory cells around the suture thread compared to the other groups. The exudative phase was more exacerbate in G1, especially due to this higher accumulation of inflammatory cells. Fibrin glue may have somehow contributed to moderating the exudative phase, facilitating fibroplasia.

In the proliferative phase, however, connective tissue formation was more pronounced in the groups receiving fibrin glue. These results are in agreement with healing reaction descriptions in free gingival grafts using fibrin glue derived from snake venom. In this 
J. R. E. de Moraes et al. EXPERIMENTAL USE OF FIBRIN GLUE DERIVED FROM SNAKE VENOM IN NONPREGNANT CANINE UTERUS. J. Venom. Anim. Toxins incl. Trop. Dis., 2004, 10, 2, p.141.

study, there was a less marked inflammatory infiltrate and marked presence of fibroblasts in these grafts (8). In the fibrin only group, as the exudative phase was more moderate, connective proliferation and angiogenesis occurred more rapidly and easily, favoring fibroplasia. In addition, the fibrin present in the glue helps in the formation of a connective foundation, where the cells can proliferate and form a scar. The glue action is due, at least in part, to the incorporation of fibrin in the extra-cellular conjunctive matrix (14), forming more exuberant scar granulation tissue. Our results show that fibroplasia was facilitated by the presence of fibrin.

\section{CONCLUSIONS}

The experimental model was appropriate for achieving the proposed objectives.

The use of fibrin glue produced less inflammation in the exudative phase and facilitated the evolution of the proliferative and maturation phases, leading to angiogenesis and more exuberant connective proliferation.

Fibrin glue derived from snake venom can be used with promising results as an adjuvant and sealant in uterus of bitches.

\section{REFERENCES}

1 BASSU S., MARINI CP., BAUMAN G., SHIRAZIAN D., DAMIAN P., ROBERTAZZI R., JACOBOWITZ IJ., ACINAPURA A., CUNNINGHAM JR JN. Comparative study of biological glues. Cryoprecipitate glue, twocomponent fibrin sealant, and "French" glue. Am. Thorac. Surg., 1995, 60, 1255-62.

2 CHALHOUB M., PRESTES NC., LOPES MD., ROCHA NS., THOMAZINISANTOS IA., MENDES-GIANNINI MJ. The use of snake venom derived 
J. R. E. de Moraes et al. EXPERIMENTAL USE OF FIBRIN GLUE DERIVED FROM SNAKE VENOM IN NONPREGNANT CANINE UTERUS. J. Venom. Anim. Toxins incl. Trop. Dis., 2004, 10, 2, p.142.

fibrin glue in hysterorrhaphy of ovine caesarean surgery. J. Venom. Anim. Toxins, 2000, 6, 220-37. (SciELO)

3 COSTA R., FERREIRA P., FERREIRA M., CASTRO R., ARAÚJO F. Eficácia da cola de fibrina no tratamento da fístula broncopleural. Acta Pediatr. Por., 1998, 29, 279-182.

4 FONTES CE., FERREIRA MV., PRADO OFO., SOUZA DF., PANERARI AC., MEDINA AR., LIMA TG. Estudo comparativo do reparo de ferimento de fígado com cola de fibrina e cianoacrilato. Acta Cir. Bras. In press 2003.

5 LEITE CVS., NARESSE LE., SAAD LHC. Cicatrização intestinal - efeito da cola de fibrina derivada de veneno de cobra na anastomose do cólon de ratos. In: CONGRESSO BRASILEIRO DE COLO-PROCTOLOGIA, 43, Recife, 1994. Anais...Recife: Sociedade Brasileira de Colo-proctologia, 1994. 12.

6 LERNER R., BINUR NS. Current research review - Current status of surgical adhesives. J. Surg. Res., 1990, 48, 165-81.

7 MORAES AM., ANNICHINO-BIZZACCHI JM., ROSSI ABR. Use of autologous fibrin glue in dermatologic surgery: application of skin graft and second intention healing. São Paulo Med. J., 1998, 116, 1747-52.

8 OLIVEIRA MDB. Aplicação de adesivo de fibrina derivado de veneno de serpente para a imobilização de enxertos gengivais livres: estudo clínico e histológico. Bauru: Universidade de São Paulo, Faculdade de Odontologia de Bauru, 2001. 68p. [Tese-Doutorado].

9 REIS FA. A comparative study of axonal sprouting from the vagus nerve in autologous grafts. J. Venom. Anim. Toxins, 2000, 6, 120. (SciELO)

10 SARTORI-FILHO R., PRESTES NC., THOMAZINI-SANTOS IA., MENDESGIANNINI MJS., TOSCANO E., CANAVESI AMO., BARRAVIERA B. Use of fibrin glue derived from snake venom in the testicular biopsy of rams. $\boldsymbol{J}$. Venom Anim. Toxins, 1998, 4, 23-35. (SciELO) 
J. R. E. de Moraes et al. EXPERIMENTAL USE OF FIBRIN GLUE DERIVED FROM SNAKE VENOM IN NONPREGNANT CANINE UTERUS. J. Venom. Anim. Toxins incl. Trop. Dis., 2004, 10, 2, p.143.

11 STOLF HO. Uso do adesivo tecidual de fibrina derivado de veneno de serpente e avaliação da técnica de autoenxertia utilizando a pele do sulco nasogeniano. São Paulo: Universidade Federal de São Paulo, Faculdade de Medicina, 1998. 115p. [Tese-Doutorado].

12 STOLF HO., BARRAVIERA SRCS., THOMAZINI IA. Cola de fibrina derivada de veneno de cobra. Uso experimental em cirurgia dermatológica. In: CONGRESSO BRASILEIRO DE DERMATOLOGIA, 48, Curitiba, 1993. Anais...Curitiba: Sociedade Brasileira de Dermatologia, 1993. 168.

13 THOMAZINI-SANTOS IA. Adesivo de fibrina derivado de veneno de serpente: efeito da adição do ácido epsilon-aminocapróico, do ácido tranexâmico e da aprotinina na coaptação das bordas cirúrgicas em incisões de pele de ratos. Botucatu: Universidade Estadual Paulista, Faculdade de Medicina, 2000. 125p. [Tese-Doutorado].

14 VICENTE EJD., RODRIGUES AC., REIS FA., THOMAZINI-SANTOS IA. Suture versus fibrin adhesive: a comparative study in the peripheral nerve repair. In: WORKSHOP INTERNATIONAL DE MICROCIRURGIA DE MÃO, 5, Botucatu, 2000. Resumos... Botucatu: Sociedade Brasileira de Ortopedia e Traumatologia, 2000. 14.

15 WEIGEL PH., FULLER GM., LEBOEUF RD. A model for the role of hyaluronic acid and fibrin in the early events during the inflammatory response and wound healing. J. Theor. Biol., 1986, 2, 219-34.

16 ZERDERFELDT B. Does fibrin play a important role in wound healing? In: SCHLAG G., REDL H. Wound healing. Berlin: Springer-Verlag, 1994. 